\section{The effect of absorptive capacity on the financial performance of Brazilian and Portuguese companies in a low technological intensity sector}

\author{
Juliane Laviniki ${ }^{1}$ \\ ju.laviniki@hotmail.com | (ㄷ) 0000-0002-1953-3080 \\ Claudionor Guedes Laimer ${ }^{1}$ \\ claudionorlaimer@gmail.com | (1) 0000-0001-5696-8043 \\ Carlos Rodrigues ${ }^{2}$ \\ cjose@ua.pt | (100000-0001-6403-6959 \\ João Lourenço Marques ${ }^{2}$ \\ jjmarques@ua.pt | (D) 0000-0003-0472-2767
}

\begin{abstract}
The digital transformation has driven a more assertive absorption of external information and knowledge in all economic activities, especially in the low technological intensity sector, where competition has been fierce. In this way, the use of information and knowledge can provide companies with higher performance before its competitors. Thus, this study seeks to verify the effect of absorptive capacity (ACAP) on the financial performance of Brazilian and Portuguese companies that operate in low technological intensity sectors. The study is part of initial research that addresses ACAP in sectors that do not release innovations in the market. A survey was carried out based on validated scales, but adapted to the low technology sector. Then, a new validation of the scales was carried out and a t-test was performed to check if there are differences and regression analysis to answer the hypotheses. The results showed that ACAP has an effect on financial performance, both in the Brazilian and Portuguese context, being higher in Portuguese companies. In addition, it was also shown that the two dimensions of ACAP have different influences on financial performance, when considering the two contexts. It can be concluded that ACAP can be applied in sectors of low technological intensity, as this has an influence over the financial performance of companies.
\end{abstract}

\section{KEYWORDS}

Strategy, absorptive capacity, innovation, performance, low technological intensity sector
${ }^{1}$ IMED - Business School, Passo Fundo, RS, Brasil

${ }^{2}$ University of Aveiro, Aveiro, Portugal

Received: 04/01/2020.

Revised: 08/26/2020.

Accepted: 12/21/2020.

Published Online: $07 / 26 / 2021$

DOI: http://dx.doi.org/10.15728/bbr.2021.18.5.4 


\section{INTRODUCTION}

Absorptive Capacity (ACAP) has been identified as a factor that provides a competitive advantage (Roberts et al., 2012; Zahra \& George, 2002), as it is related to innovation (Flor et al., 2018; Tsai, 2001; Xie et al., 2018), information and knowledge transfer (Giuliani \& Bell, 2005; Sroka et al., 2014), and organizational learning (Biedenbach \& Müller, 2012; Lane et al., 2006; Yu, 2013). Thus, ACAP has been considered an intangible resource, one that is difficult to imitate and one that can contribute as a source of competitive advantage for a company (Jiménez-Barrionuevo et al., 2011).

ACAP, grouped with adaptive capacity and innovative capacity, make up the company's dynamic capabilities (Wang \& Ahmed, 2007). Dynamic capabilities have been considered essential for consolidating competitiveness and for creating and/or maintaining the company's competitive advantage, especially in a dynamic environment (e.g., sectors of high technological intensity - semiconductor industry) of rapid change (Eisenhardt \& Martin, 2000). ACAP is generally related to the company's ability to absorb external knowledge, transforming it into innovations (Biedenbach \& Müller, 2012; Flor et al., 2018; Giuliani \& Bell, 2005; Hernández-Perlines \& Xu, 2018; Tsai, 2001).

Due to the relevance of the theme, it has been researched in companies at the industrial sector (Kim \& Lee, 2018; Muscio, 2007; Spithoven et al., 2011), in companies at high-tech sectors (Burcharth et al., 2015; Fernández et al., 2012; Flor et al., 2018; Leal-Rodríguez \& Roldán, 2013; Patterson \& Ambrosini, 2015), in clusters and networks (Giuliani \& Bell, 2005; Tsai, 2001; Wegner et al., 2013), in rural producers (Adejuwon, 2016) and in family businesses (Ferreira $\&$ Ferreira, 2017; Hernández-Perlines \& Xu, 2018). However, scarce attention has been given to companies that operate in sectors of low and medium technological intensity (Abbate et al., 2020), as well as companies from different countries (e.g., Pereira and Leităo, 2016; Martins, 2016; Sánchez and Toro-Jaramillo, 2018; Wang and Rafiq, 2014).

The studies have been concentrated on companies of high technological intensity in developed countries (Tzokas et al., 2015; Wang \& Rafiq, 2014). Although these studies have made it possible to investigate the role of absorptive capacity in innovation and performance, studies in low technological intensity companies in developing countries (Hervas-Oliver et al., 2012) or emerging economies are rare (Del Carpio-Gallegos \& Miralles-Torner, 2018; Geldes et al., 2017), especially in the service sector (e.g., trade, transport, construction and real estate).

In addition, there is a lack of greater understanding of the results of ACAP, since there is a consensus in the literature that ACAP leads to innovation and innovation leads to financial performance (Ali et al., 2016; Guo et al., 2017; Kostopoulos et al., 2011; Liu et al., 2018), although the seminal work of Zahra and George (2002) highlighted the relationship between ACAP and performance, studies diverge on the direct effect of ACAP on the company's financial performance. Thus, there is a need to investigate the relationship of ACAP and financial performance, especially with regard to the direct effect of ACAP on financial performance, as some studies indicate that the effects are limited (Zou et al., 2018). Therefore, the question is, to what extent does ACAP have a direct effect on the company's financial performance (Wang et al., 2015).

However, in order to increase the validity of ACAP as a construct, considering its dimensions and its components, it is important that studies investigate its effects on the company's performance (Jansen et al., 2005) and test and replicate its theoretical assumptions in environments of different technological, economic and cultural conditions (Kostopoulos et al., 2011; Volberda et al., 2010). In this sense, the effect of ACAP on the company's financial performance depends on the dynamism of the market (Schilke, 2013), the technological intensity of the sector (e.g., low, 
medium or high technological intensity) and the economic and cultural context (e.g., Brazil and Portugal) in which it operates (Kostopoulos et al., 2011).

In this context, the absorptive capacity implies recognizing and using external information and knowledge for commercial purposes (Cohen \& Levinthal, 1990). Although there are theoretical and empirical studies that emphasize its positive results in relation to the company's competitive advantage (Volberda et al., 2010; Zahra \& George, 2002), measured by financial performance, the crucial issue is to present evidence in a low technological sector and in different contexts (e.g., Brazil and Portugal). In other words, does ACAP trigger an effect on the financial performance of low technological intensity companies? If so, does this effect occur in the same way in Brazilian and Portuguese companies?

Thus, this study seeks to answer the following research question: what is the effect of absorptive capacity (ACAP) on the financial performance of Brazilian and Portuguese companies that operate in the low technological intensity sector? Thus, this study is directed to the effect that ACAP unleashes on the financial performance of companies, in relation to its dimensions (i.e., potential and realized) and its components: acquisition; assimilation; transformation; and exploration (Zahra \& George, 2002). They are the central contribution of this study, as they are distinct from other studied constructs, highlighting the fact that the absorption of information and external knowledge is a risky and challenging activity that demands more from companies than internal communication (Burcharth et al., 2015).

With this, this study aims to verify the effect of absorptive capacity (ACAP) on the financial performance of Brazilian and Portuguese companies that operate in a low technological intensity sector. Thus, it was decided to investigate Brazilian and Portuguese companies that operate in the real estate sector, and this decision is based on the fact that the basis of their modus operandi is the use of external information and knowledge. The real estate market is characterized by the intense use of information and knowledge, and companies benefit from the information asymmetry itself (Akerlof, 1970).

The real estate sector has low investment in $\mathrm{R} \& \mathrm{D}$ as a structural characteristic (GalindoRueda \& Verger, 2016), however, the changes resulting from the digital transformation and the dynamism of the market is pushing companies to incorporate the use of digital technologies (e.g., digital platforms for sales and leasing activities), which may increase the effects of ACAP. In a previous survey, it was observed that the stage of development of the real estate business in Brazil and Portugal is similar, which makes it possible to highlight possible similarities and differences between companies in both contexts. Likewise, it is possible to highlight aspects related to the proximity of cultural order (linguistic, historical, and cultural affinities) between Brazil and Portugal (Costa, 2006; Silva, 2005).

The research aims to contribute to the advancement of studies on ACAP, identifying the influence in sectors that use innovations, that is, that are not involved in intensive investments in R\&D for the development of innovations (Lane et al., 2006). Thus, it is considered relevant to investigate the effect of ACAP in sectors of low technological intensity, which have low investment in R\&D (Galindo-Rueda \& Verger, 2016). Thus, when verifying whether there is influence of ACAP on the financial performance of companies and if it occurs differently in Brazilian and Portuguese companies, it may represent an important contribution to the literature, as it investigates the relationship between ACAP and financial performance in a specific sector and in different contexts, but which have similarities. 


\section{ABSORPTIVE CAPACITY}

The field of organizational strategy seeks to understand why some companies perform better than others (Barney \& Arikan, 2001). Thus, RBV (Resource-Based View) appears, considered as one of the main theoretical currents about competitive advantage, initially developed by Wernerfelt (1984), based on the work of Penrose (1959). Although it received many contributions, especially from Barney (1986, 1991), the RBV presented some gaps and, with that, Teece et al. (1997)`s proposal on dynamic capacities emerged, which are composed of three types: absorptive capacity, adaptive capacity, and innovative capacity (Wang \& Ahmed, 2007).

On the other hand, ACAP was initially discussed by Cohen and Levinthal (1990), as the ability that a company possesses in recognizing the value of new external information, assimilating it and applying it for commercial purposes. Thus, ACAP was characterized by three components: acquisition, assimilation and exploration. In the evolution of the ACAP studies and in its reconceptualization, another component was identified, the transformation (Zahra \& George, 2002). Although several revisions of the ACAP reconceptualization have emerged (Kale et al., 2019; Todorova \& Durisin, 2007), the reconceptualization of Zahra and George (2002) has been used predominantly in the literature.

In this sense, ACAP came to be understood by four components (acquisition, assimilation, transformation and exploitation) and two dimensions (potential and realized), organized as follows (Zahra \& George, 2002): the Potential Absorptive Capacity (PACAP) composed by acquisition and assimilation; and the Realized Absorptive Capacity (RACAP) composed of transformation and exploration (Figure 1). Although the reconceptualization of ACAP has been tested empirically and theoretically refined (Jansen et al., 2005; Lane et al., 2006), some limitations still persist, as studies on ACAP have only begun to explore components and dimensions (Volberda et al., 2010).

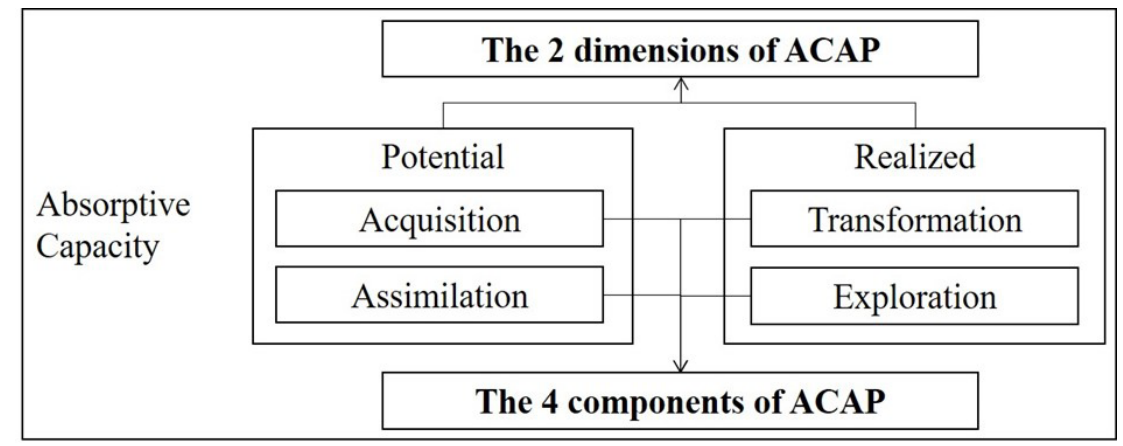

Figure 1. Absorptive capacity with its dimensions and components Source: Adapted from Zahra and George (2002).

Acquisition refers to the ability to identify and acquire external knowledge that is important to the company's operations (Kamal \& Flanagan, 2012). It reflects the company's ability to use external information (Flatten, Engelen et al., 2011). Assimilation is related to the routines and processes developed by the company to foster the analysis, processing, interpretation and understanding of the external information obtained. Flatten, Engelen et al. (2011) affirm that assimilation is related to internal capacities regarding the flow of information and ideas between departments of the company. These two components make up the PACAP that captures the company's efforts in the search to obtain and incorporate new external knowledge (Camisón \& Forés, 2010; Cruz \& Corrêa, 2018). 
The transformation, on the other hand, indicates the company's ability to develop and improve internal routines that provide greater ease in combining previous knowledge with the newly acquired and assimilated knowledge. It refers to the ability to process the knowledge acquired by the company (Flatten, Engelen et al., 2011). For the authors, this component reflects the ability to structure and use the new knowledge by associating it with previous knowledge. Finally, exploration, which is related to the company's ability to refine, expand and leverage existing skills or create new ones due to the ability to incorporate the knowledge acquired and imbued into its operations (Zahra \& George, 2002). This component is related to commercial exploitation based on new knowledge. These two components together make up the RACAP, which reflects how companies shape and apply the external knowledge assimilated (Cruz \& Corrêa, 2018), that is, it demonstrates the transformation of knowledge (Camisón \& Forés, 2010).

The dimensions and components of ACAP can be complementary and can also overlap due to integrating organizational processes and routines (Cruz \& Corrêa, 2018), but they can also compose a sequential process - from potential to realized.

As defended by Zahra and George (2002), the distinction in two dimensions is necessary due to the fact that some companies are able to acquire and assimilate information (PACAP), but are unable to use this knowledge (RACAP). Thus, a clearer way of understanding this division in two dimensions is that PACAP represents the company's ability to acquire and assimilate external knowledge (Cassol et al., 2016). That is, it represents the ability to seek external knowledge that may or may not be used later (Flor et al., 2018), which signals the movement from outside towards inside. Thus, a company may be able to expand its knowledge base or continually renew its knowledge stock, but it may have to bear the costs of acquiring information and knowledge without obtaining an expected return, that is, this in itself does not necessarily lead to superior performance (Brettel et al., 2011; Flatten, Greve et al., 2011; Volberda et al., 2010).

RACAP, on the other hand, represents the ability to use absorbed knowledge (Cassol et al., 2016), that is, it signals an internal movement. As a result, a company focused on transformation and exploration (i.e., RACAP) can make greater profits in the short term (Jansen et al., 2005), although it may not be guaranteed to keep them in the long term, as it may not develop a base of new information and knowledge (Brettel et al., 2011). However, these findings indicate that the components may have different effects on the dimensions of the ACAP, and the dimensions may affect the company's financial performance differently (Jansen et al., 2005; Patel et al., 2015).

Therefore, ACAP has been considered a research field in ongoing exploration and several studies have been published on the topic, which identify the direct or indirect influence of ACAP on innovation, performance, access to resources, among others, since ACAP is considered an input that enables the development and commercialization of products and services (Martins, 2016). Therefore, knowledge, the basis for ACAP, is seen as central to maintaining organizational skills (Cho, 2014). Knowledge can be obtained in two ways: by internal effort, which is sometimes not enough, and by external resources (Cho, 2014). This is where the companies with the greatest ACAP stand out, as they have the greatest capacity to identify the importance of external knowledge to which they have access.

Recently, Liao et al. (2019) identified that while developing ACAP with the objective of improving financial performance, the company was able to display a distinct strategic value. Likewise, Cassol et al. (2016) identified that ACAP influences innovation and companies have managed to increase competitiveness and adapt to the environment through it. That is, companies are able to obtain or maintain their competitive advantage through ACAP. 
Regarding the effect of ACAP on financial performance, it is also possible to highlight some studies. ACAP has a moderating effect on the relationship between the company's centrality in the network and its financial performance (Kim \& Lee, 2018). In the construction sector, it was identified that some companies presented ACAP, which influences financial performance, however, only when it is associated with the employment of qualified professionals with skills for the given activity (Gann, 2010). On the other hand, Spithoven et al. (2011) state that the civil construction sector, among others, has a relatively low and often negative ACAP. This is an important argument, since ACAP is identified as a vital factor to improve the financial performance of companies (Biedenbach \& Müller, 2012; Roberts et al., 2012). Thus, the following research hypothesis is formulated:

- Hypothesis $1\left(\mathbf{H}_{1}\right)$ : ACAP exerts a positive effect on the company's financial performance.

Garzón-Castrillón (2016) reinforces the importance of PACAP as a process that renews the internal knowledge bases to compete in this ever-changing market, which provides strategic flexibility to adapt. Having a dynamic and flexible PACAP makes it easier for companies to reconfigure themselves and take advantage of strategic opportunities (Garzón-Castrillón, 2016). Thus, companies with well-developed PACAP tend to be better able to continuously renew their stock of knowledge, detecting trends in their external environment and internalizing this knowledge (Flor et al., 2018).

Meanwhile, that RACAP is composed by the transformation and exploitation of the knowledge acquired from external sources, seen as a complex process (Garzón-Castrillón, 2016). Camisón and Forés (2010) argue that the ability to explore knowledge is the basis for superior performance, when compared to the ability to create knowledge.

The need to analyze the constructs separately is due to the fact that some companies may have high levels of PACAP, but low capacity to exploit this knowledge, that is, low levels of RACAP (Vega-Jurado et al., 2008). On the other hand, a low level of PACAP with a high level of RACAP indicates that the company has the capacity to leverage and exploit knowledge, however it is not able to effectively acquire and /or assimilate it (Leal-Rodríguez \& Roldán, 2013). Therefore, companies differ in their ability to assimilate and replicate new knowledge acquired (Lee \& Wu, 2010). Thus, the following research hypotheses are proposed:

- Hypothesis 2a $\left(\mathbf{H}_{2 \mathbf{a}}\right)$ : PACAP exerts a positive effect on the company's financial performance.

- Hypothesis $\mathbf{2 b}\left(\mathbf{H}_{2 \mathbf{b}}\right)$ : RACAP exerts a positive effect on the company's financial performance.

Thus, the advantages and benefits of PACAP outweigh the costs of acquiring information and knowledge at the outset, but other factors are incorporated over time (e.g., structuring the knowledge acquired, formalizing the coordination system), leading to higher costs in relation to benefits (Brettel et al., 2011), in such a way that the scarcity of resources can lead to a trade-off between expanding or not investing in technological solutions (e.g., intelligent digital platforms), in order to expand the knowledge base, which may have a positive effect on performance financial.

In the case of RACAP, the new knowledge base acquired and assimilated is used with the intention of improving the company's financial performance (Patel et al., 2015), since the costs incurred in the transformation and exploration of knowledge, integrated with operational activities, must be considered to make the company more profitable (Brettel et al., 2011). Initially, companies have higher costs in developing RACAP, but over time, costs stabilize, with higher levels of financial 
performance. Thus, contrary to what happens in the development of PACAP, RACAP does not need to respond quickly to changes in the dynamic market environment.

Likewise, in the study by Kale et al. (2019) it was observed, from a reorganization of the components and dimensions, that the acquisition dimension (acquisition component) does not have a direct effect on the company's financial performance, while the usage dimension (assimilation, transformation, and exploration components) has a direct effect on the company's financial performance. In general, the tests of the relationship between ACAP and financial performance, or the dimensions of ACAP and financial performance, have confirmed that there is an effect of ACAP on the company's financial performance and that this effect is positive and significant (Flatten, Greve et al., 2011; Kostopoulos et al., 2011; Shoham et al., 2017).

The collective analysis of the dimensions is relevant, as each of them contributes differently to financial performance (Chauvet, 2014, Patel et al., 2015). In addition, all research hypotheses will be analyzed in two contexts (i.e., Brazil and Portugal), among Brazilian companies and Portuguese companies, similar to other studies (Pereira \& Leitão, 2016; Sánchez \& Toro-Jaramillo, 2018). The real estate sectors in Brazil and Portugal, more specifically, in the activity of buying, selling and renting real estate, are at a similar stage of development, with the use of similar routines and processes (e.g., use of digital platforms). Although there is a proximity of cultural order (linguistic, historical, and cultural affinities) between Brazil and Portugal (Costa, 2006; Silva, 2005), it is possible to highlight possible similarities and differences between companies in both contexts. Thus, it may be possible to verify the effect of ACAP on the financial performance of low technological intensity companies in different contexts.

\section{METHOD}

The present study is a research with a quantitative approach, of a descriptive nature and transversal character. The population chosen for the research comprises the real estate sector, in Passo Fundo, Brazil and in Aveiro, Portugal. The Brazilian and Portuguese context are characterized by two cities that present indicators above the national average in the real estate sector, whether linked to the economic activities of construction and/or linked to the economic activity of buying, selling, and renting real estate.

The choice of the sector took into account the low investment in $\mathrm{R} \& \mathrm{D}$, which results in low technological intensity (Galindo-Rueda \& Verger, 2016). In addition, the choice of the real estate sector was due to the intense use of external information and knowledge (Akerlof, 1970), despite not being a high technological intensity sector (Melo et al., 2015), has been experimenting with new digital technologies that involve everything from real estate management to aspects inherent to consumer behavior. Due to the intense absorption and use of information and knowledge, the sector makes it possible to test the effect of ACAP on the financial performance of companies.

The research sample consisted of 29 real estate agencies in Aveiro (Portugal) from a total of 68 companies with activities for buying, selling, and leasing properties in the municipality (Instituto Nacional de Estatística [INE], 2019) and 43 real estate companies in Passo Fundo (Brazil) from a total of 124 companies with activities for buying, selling, and leasing properties in the municipality (Ministério da Economia, 2019). The exploratory research in government databases indicated the total number of companies in each municipality, making it possible to dimension and prepare a list for data collection. Thus, the convenience sampling technique was used, considering accessibility and availability to participate in the research. 
Data collection was carried out in Portugal and later in Brazil. This collection took place through a survey, a semi-structured questionnaire in three blocks: the first held questions about the characterization of the sample; the second on the indication of companies in the sector to contact (snowball technique); and the third block held scales to test the research hypotheses. The scale for measuring the variables was a Likert type (expanded) of 11 points, with a range from 0 (strongly disagree) to 10 (strongly agree). The choice for the expanded measurement scale considered the level of education of the respondents (i.e., entrepreneurs and/or managers) and also because it is a usual and familiar way in Brazil and Portugal to refer to the attribution of value, with 0 signaling the absence of attribute and 10 as the maximum intensity for the attribute (Hodge \& Gillespie, 2003). The research variables were as follows:

Control variables (age and size) - two control variables were used, as it is understood that they can impact the results. Age was measured by the company's years of existence, being cited as an important control variable. It impacts the market experience (Mazzola et al., 2016) and the use of information and knowledge (Gwebu et al., 2018), which can contribute to greater performance (Wegner et al., 2013). Size (i.e., company size) was measured by the number of employees, which can impact the transfer of information and knowledge and performance (Maurer et al., 2011).

Independent variables (ACAP, PACAP and RACAP) - ACAP is considered a single construct (Wang \& Ahmed, 2007) or composed by its four components (Jansen et al., 2005; Xie et al., 2018). For this study, an adaptation of the already validated scale was considered, composed of four components of the ACAP (Camisón \& Forés, 2010; Flatten, Engelen et al., 2011; NajafiTavani et al., 2018), being that variables that addressed innovation were excluded. The ACAP construct was formed by the average of the responses referring to its four components (i.e., acquisition, assimilation, transformation, and exploration), PACAP was formed by the average of the responses of two components (i.e., acquisition, assimilation) and, finally, the RACAP was formed by the average of the responses of the other two components (i.e., transformation and exploration), as addressed in the literature.

Dependent variable (performance) - a scale with subjective measures (i.e., manager's perception) was used and validated in previous studies (Dess \& Robinson, 1984; Gwebu et al., 2018; Wegner et al., 2013). Subjective measures take into account the entrepreneur's perception as a proxy for assessing financial performance, while objective measures are obtained through data from financial reports (Wegner et al., 2013). Although objective measures are preferable, in small and medium-sized companies, they are not available due to the lack of regular accounting and/or administrative restrictions. Thus, subjective measures can be used as substitutes when it is not possible to obtain concrete data or these data are not reliable, as studies have shown that managers' perceptions are consistent with objective measures (Dess \& Robinson, 1984). Therefore, this way of measuring financial performance has been widely used in the literature (Centenaro \& Laimer, 2017; Gwebu et al., 2018; Pollanen et al., 2017; Wegner et al., 2016).

In this way, the chosen scales were translated into Portuguese and included in the questionnaire, being validated by experts from the academy and the market. After validation, the questionnaire was submitted to a pre-test, with three companies in the investigated sector, which did not require adjustments and were integrated into the database. The questionnaire was applied by the researchers themselves with the respondents (i.e., entrepreneurs and/or managers). After collection, the data were tabulated in an electronic spreadsheet for analysis in the statistical program (Statistical Package for Social Sciences [SPSS] version 21). First, the data were purified according to the following exclusion criteria: 
(i) companies with less than one year of existence, which could influence the responses on performance, since the scale requested an evaluation referring to the last years. A Portuguese company questionnaire was eliminated.

(ii) elimination of questionnaires with answers at just one end of the scale, only 0 s or only $10 \mathrm{~s}$ (Malhotra, 2012). Thus, two questionnaires from Brazilian companies were eliminated.

After refining the data, an exploratory factor analysis (EFA) was carried out to validate the adapted scale and identify groupings of the variables (Field, 2009) and the "inherent structure between the variables of the analysis" (Hair et al., 2009, p. 102). The EFA was carried out considering the variables of each of the four components of the ACAP and the performance variables, and it was decided to determine factors a priori (Malhotra, 2012), according to the respective constructs (acronym of the variables, see Appendix A). Thus, having fulfilled all the assumptions, the analysis of the factors resulted in the following structure (Table 1):

Table 1

Exploratory factor analysis

\begin{tabular}{|c|c|c|c|c|c|}
\hline Variables & Factor 1 & Factor 2 & Factor 3 & Factor 4 & Factor 5 \\
\hline CA_Acqui_2 & 0.876 & & & & \\
\hline CA_Acqui_3 & 0.794 & & & & \\
\hline CA_Acqui_4 & 0.924 & & & & \\
\hline CA_Acqui_5 & 0.776 & & & & \\
\hline CA_Assim_1 & & 0.757 & & & \\
\hline CA_Assim_2 & & 0.896 & & & \\
\hline CA_Assim_3 & & 0.908 & & & \\
\hline CA_Transf_1 & & & 0.839 & & \\
\hline CA_Transf_2 & & & 0.847 & & \\
\hline CA_Transf_3 & & & 0.852 & & \\
\hline CA_Transf_4 & & & 0.802 & & \\
\hline CA_Expl_1 & & & & 0.853 & \\
\hline CA_Expl_2 & & & & 0.883 & \\
\hline CA_Expl_3 & & & & 0.889 & \\
\hline CA_Expl_4 & & & & 0.854 & \\
\hline Perform_1 & & & & & 0.799 \\
\hline Perform_2 & & & & & 0.897 \\
\hline Perform_4 & & & & & 0.858 \\
\hline Perform_5 & & & & & 0.784 \\
\hline Perform_6 & & & & & 0.915 \\
\hline KMO & $0.736^{*}$ & $0.656^{*}$ & $0.806^{*}$ & $0.746^{*}$ & $0.791^{*}$ \\
\hline Explained Variance & $71.36 \%$ & $73.35 \%$ & $70.93 \%$ & $75.74 \%$ & $72.01 \%$ \\
\hline Alpha Coefficient & 0.865 & 0.792 & 0.862 & 0.889 & 0.902 \\
\hline
\end{tabular}

Note: Bartlett's Test of Sphericity $=\mathrm{p}<0.001$ and Kaiser-Meyer-Olkin (KMO) Test $>0.500$.

Source: Prepared by the authors. 
BBR

18

546

Therefore, the adapted scale was validated with the performance of the EFA for application in the low-tech sector. Thus, ACAP is composed of acquisition (Factor 1), assimilation (Factor 2), transformation (Factor 3) and exploration (Factor 4), while performance (Factor 5) was composed of 5 variables.

Still, we proceeded with the verification of the normality in the data distribution. Thus, the asymmetry and kurtosis of the data were verified. They are considered asymmetric when the asymmetry is \pm 3 (Kline, 2011). In addition, the data follow the normal distribution when kurtosis is \pm 10 (Yadav \& Pathak, 2016). The tests indicated normal distribution and, with that, the possibility of performing parametric tests. Thus, it was possible to verify the multicollinearity between the variables, using Pearson's correlation (Table 2). Multicollinearity indicates a problem for the multiple regression test, as it indicates a strong correlation between one of the predictor variables and the dependent variable (Field, 2009). A high multicollinearity (above 0.800) between two variables indicates that they measure the same thing and, therefore, the regression coefficients may not be accurately estimated (Malhotra, 2012). Thus, the result of the analysis can be distorted, making them unstable and not generalizable (Hair et al., 2009).

Table 2

Pearson's correlation test $(n=72)$

\begin{tabular}{lcccccccc}
\hline \multicolumn{1}{c}{ Variables } & Average & Standard Deviation & 1 & 2 & 3 & 4 & 5 & 6 \\
\hline 1 AGE & 15.79 & 12.20 & 1.000 & 0.225 & $-0.288^{*}$ & $-0.238^{*}$ & $-0.253^{*}$ & $-0.259^{*}$ \\
2 SIZE & 5.85 & 8.36 & & 1.000 & 0.166 & 0.151 & 0.171 & 0.177 \\
3 PERFORM & 7.23 & 1.78 & & & 1.000 & $0.514^{* *}$ & $0.438^{* *}$ & $0.480^{* *}$ \\
4 ACAP & 7.80 & 1.21 & & & & 1.000 & $0.915^{* *}$ & $0.851^{* *}$ \\
5 PACAP & 7.28 & 1.66 & & & & & 1.000 & $0.568^{* *}$ \\
6 RACAP & 8.27 & 1.11 & & & & & & 1.000 \\
\hline
\end{tabular}

Note: Significant correlation at the level: ${ }^{*} p<0.05$ and ${ }^{* *} p<0.001$

Source: Prepared by the authors.

The correlation test indicates that there is multicollinearity between ACAP and its dimensions. Among the other variables, multicollinearity was not identified. Bearing in mind that ACAP is formed by PACAP and RACAP, it is understandable that there is multicollinearity. In addition, as the variables are analyzed in isolation, they do not represent a problem for the research.

Finally, Student T-test was performed to identify whether there are differences in the average responses between the two groups of companies, denominated Portugal and Brazil (Table 3).

The result of the T-test indicates that there is no difference between the average values of the research variables, except for age, which is a control variable. Thus, it can be concluded that the differences in the research results did not occur due to differences in the responses between the groups. 
Table 3

Student T-test

\begin{tabular}{clcccc}
\hline Variable & Group & Number of companies & Average & Standard Deviation & Student T-test \\
\hline \multirow{2}{*}{ AGE } & Portugal & 29 & 12.03 & 10.29 & $-2.203^{*}$ \\
& Brazil & 43 & 18.33 & 12.84 & \\
\multirow{2}{*}{ SIZE } & Portugal & 29 & 6.03 & 6.53 & 0.155 \\
& Brazil & 43 & 5.72 & 9.47 & \\
\multirow{2}{*}{ PERFORM } & Portugal & 29 & 7.68 & 1.70 & 1.824 \\
& Brazil & 43 & 6.92 & 1.79 & \\
\multirow{2}{*}{ ACAP } & Portugal & 29 & 7.83 & 1.11 & 0.093 \\
& Brazil & 43 & 7.80 & 1.30 & \\
\multirow{2}{*}{ PACAP } & Portugal & 29 & 7.11 & 1.56 & -0.779 \\
& Brazil & 43 & 7.41 & 1.68 & \\
& Portugal & 29 & 8.47 & 1.10 & 1.224 \\
\hline
\end{tabular}

Note: Significant T-test at the level: ${ }^{*} p<0.05$

Source: Prepared by the authors.

\section{RESULTS AND DISCUSSIONS}

The results analysis shows that the average age of real estate agents in Portugal is 12 years old $(12.03 \pm 10.29)$, with the youngest only one year old and the oldest 36 years old. The average number of employees is $6(6.03 \pm 6.53)$ with a minimum of one and a maximum of 35 employees. In Brazil, the average age of real estate agents is 18 years old $(18.33 \pm 12.84)$, with the youngest one year old and the oldest 50 years old. As for the number of employees, the average was 5 employees $(5.72 \pm 9.47)$ with a minimum of 1 and a maximum of 60 employees.

The effect of ACAP on the companies' financial performance was verified from the linear regression analysis (Table 4). The analysis verified the effect of control variables (i.e., age and size) on the financial performance of Portuguese (model 1) and Brazilian (model 5) companies, while the effect of ACAP on the financial performance of Portuguese (model 2) and Brazilian (model 6) companies. Likewise, the effect of PACAP on the financial performance of Portuguese (model 3 ) and Brazilian (model 7) companies was verified, while the effect of RACAP on the financial performance of Portuguese (model 4) and Brazilian (model 8) companies was also verified.

First, it is possible to identify that the control variables, age and size, do not have a positive and significant effect on the performance variable, regardless of the context (i.e., Portugal or Brazil), although there is an indication that these variables may interfere with experience (Mazzola et al., 2016), performance (Wegner et al., 2013) and the transfer of information and knowledge (Gwebu et al., 2018; Maurer et al., 2011). Thus, it can be said that the results of the other regression models have the direct effect of the independent variable (i.e., ACAP, PACAP and RACAP) on the dependent variable, without interference from the control variables. Thus, the variables age and size do not influence the financial performance of companies in the real estate sector investigated. 
Table 4

Linear Regression Test

\begin{tabular}{|c|c|c|c|c|c|c|c|c|}
\hline \multirow[b]{2}{*}{ Variables } & \multicolumn{4}{|c|}{ Portugal } & \multicolumn{4}{|c|}{ Brazil } \\
\hline & $\begin{array}{c}\text { Model } 1 \\
\text { Control } \\
\text { x Perform }\end{array}$ & $\begin{array}{c}\text { Model } 2 \\
\text { ACAP } \\
\text { x Perform }\end{array}$ & $\begin{array}{l}\text { Model } 3 \\
\text { PACAP x } \\
\text { Perform }\end{array}$ & $\begin{array}{l}\text { Model } 4 \\
\text { RACAP x } \\
\text { Perform }\end{array}$ & $\begin{array}{l}\text { Model } 5 \\
\text { Control x } \\
\text { Perform }\end{array}$ & $\begin{array}{c}\text { Model } 6 \\
\text { ACAP } \\
\text { x Perform }\end{array}$ & $\begin{array}{l}\text { Model } 7 \\
\text { PACAP x } \\
\text { Perform }\end{array}$ & $\begin{array}{l}\text { Model } 8 \\
\text { RACAP x } \\
\text { Perform }\end{array}$ \\
\hline Intercept & 7.714 & 0.744 & 4.436 & 0.443 & 7.397 & 2.185 & 3.128 & 2.670 \\
\hline Age & -0.181 & 0.002 & -0.050 & -0.056 & -0.277 & -0.097 & 0.070 & -0.163 \\
\hline Size & 0.209 & 0.059 & 0.056 & 0.181 & 0.214 & 0.090 & 0.089 & 0.122 \\
\hline ACAP & & $0.570^{*}$ & & & & $0.456^{*}$ & & \\
\hline PACAP & & & $0.422^{*}$ & & & & $0.492^{*}$ & \\
\hline RACAP & & & & $0.540^{*}$ & & & & $0.347^{*}$ \\
\hline $\mathrm{R}^{2}$ & 0.065 & 0.343 & 0.208 & 0.342 & 0.090 & 0.262 & 0.288 & 0.195 \\
\hline $\mathrm{R}^{2}$ Adjusted & -0.007 & 0.264 & 0.113 & 0.263 & 0.045 & 0.205 & 0.233 & 0.133 \\
\hline
\end{tabular}

Note: Significant at the level: ${ }^{*} p<0.05$

Source: Prepared by the authors.

As for the effect of ACAP on financial performance, the model has influence in both contexts (i.e., Portugal and Brazil), with $\mathrm{H}_{1}$ being accepted. However, the influence of ACAP on financial performance in Portugal (34.3\%) is greater than the influence presented in Brazil (26.2\%). This result is important, since the sector related to civil construction is pointed out as a sector with relatively low and often negative ACAP (Spithoven et al., 2011), since ACAP is generally associated with innovation and high-tech sectors (Flor et al., 2018; Hernández-Perlines \& Xu, 2018; Tsai, 2001; Xie et al., 2018).

On the other hand, ACAP is indicated as an essential element for the adaptation of companies in competitive environments (Camisón \& Forés, 2010). The real estate sector has been identified as a competitive sector that is inserted in a dynamic market (Alves et al., 2010), in such a way that the positive effect of ACAP on financial performance can help to improve the competitiveness of real estate companies. Although ACAP can increase a company's financial performance to some extent, it is necessary to develop its capabilities permanently so as not to be surprised with a negative effect on performance (Kale et al., 2019).

In addition, the effects of PACAP and RACAP on financial performance behave differently in the contexts investigated (Figure 2), with $\mathrm{H} 2 \mathrm{a}$ and $\mathrm{H} 2 \mathrm{~b}$ being accepted. In the Portuguese context, the results indicate a lesser influence of PACAP $(0.422, \mathrm{p}<0.05)$ on financial performance than RACAP $(0.540, \mathrm{p}<0.05)$. In the Brazilian context, the results were reversed, indicating a greater influence of PACAP $(0.492, \mathrm{p}<0.05)$ on financial performance than RACAP $(0.347, \mathrm{p}$ $<0.05)$. These results indicate that dimensions contribute differently to financial performance (Chauvet, 2014), especially in low technology intensity sectors and in different contexts (e.g., Brazil and Portugal). Thus, companies need to identify mechanisms that can facilitate or hinder absorption in each of the dimensions.

The results of Brazilian companies are similar to those found in Valencia (Spain), which indicates that the (potential) capacity to acquire and assimilate information and external knowledge exceeds the company's (ability) to transform and explore (Vega-Jurado et al., 2008). This result is explained by Lee and Wu (2010), who stated that companies differ in their ability to assimilate and replicate the new knowledge acquired. 


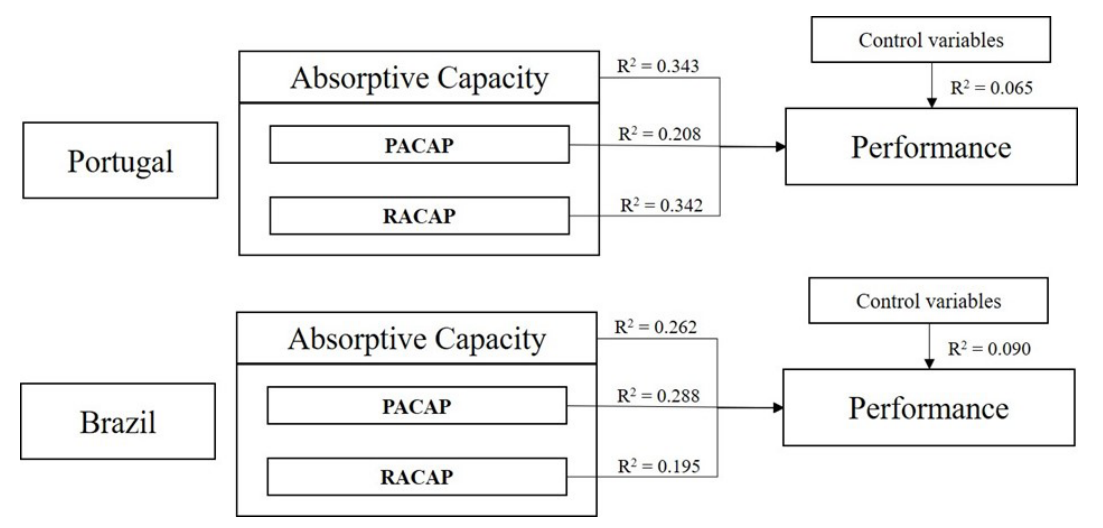

Figure 2. Results of the Regression tests

Source: Prepared by the authors.

Despite the difference between PACAP and RACAP, the results indicate that Brazilian companies are able to identify and monitor changes in the sector more effectively (Flor et al., 2018). This can facilitate the adaptation and implementation of new capabilities developed, as the company has accumulated prior knowledge. In addition, a larger PACAP is ideal when companies are in the early stages of economic activity, bearing in mind that companies have greater flexibility to adapt in (moderately) dynamic contexts (Zahra \& George, 2002).

On the other hand, Portuguese companies have a greater capacity to transform and exploit the information and external knowledge acquired, making better use for the development of their activities, since the information and knowledge acquired and assimilated (PACAP) will not be transformed and exploited immediately, but can be accumulated and used according to the needs and market conditions (Camisón \& Forés, 2010). Thus, in order to make better use of the information and knowledge acquired and assimilated, it must be shared among members of the company and integrated into the knowledge that is internally generated (Flor et al., 2018).

Thus, the development of PACAP and RACAP are related to financial performance, although PACAP is focused on responding quickly to changes in the dynamic market environment while RACAP is focused on converting operational activities into financial results (Zou et al., 2018). Thus, the financial performance of ACAP can be observed in two ways: (1) The knowledge acquired and assimilated can provide benefits, based on information and market knowledge, in order to enhance the commercialization and marketing of the services offered; (2) The transformed and exploited knowledge is incorporated into organizational processes and routines, which can help improve the company's operational activities, influencing customer service and the quality of the service provided, resulting in cost reduction and increased profits.

Companies cannot apply knowledge without acquiring it, but some companies develop skills to make better use of the acquired knowledge (Camisón \& Forés, 2010) in such a way that the results indicate that Portuguese companies are able to better disseminate information and knowledge acquired externally, when compared to Brazilian companies. Brazilian companies acquire and assimilate information and knowledge, but have not developed sufficient capacity, in the same proportion, to transform and exploit this information and knowledge. On the other hand, Portuguese companies have managed to better develop this capacity, to the point that the transformation and exploitation of information and knowledge has a greater effect on financial performance than acquisition and assimilation. 
Some companies have difficulty and/or are unable to identify how to aggregate new knowledge to the previous one. This link between new and prior knowledge is, at the same time, the link between PACAP and RACAP. This refers to the company's ability to identify that certain information and/or knowledge is relevant, assimilating and exploring effectively in its activity. For Cho (2014), the way to make these connections must start with the understanding that the information and/or knowledge will be different at the end, as there will be a change between the initial and the final form.

In this sense, real estate companies with low capacity to acquire and assimilate information and external knowledge will have greater difficulty in obtaining financial performance related to PACAP (Shoham et al., 2017). However, Portuguese companies may have higher costs for acquiring and assimilating information and knowledge in relation to the benefits that can be generated. However, Brazilian companies may be having lower costs for acquiring and assimilating information and knowledge in relation to the benefits that can be generated.

Brazilian companies share information and knowledge about buying, selling and renting real estate, this may represent a reduction in the cost of acquisition and assimilation (PACAP). Well, there are formal and informal networks in which companies interact to cooperate in real estate activities and, also, Brazilian law allows a real estate agent to be performing its brokerage activities in several real estate companies at the same time. In addition, Brazilian companies have been investing in technological solutions (e.g., digital platforms) together, thus expanding the common information base, which may be generating a positive effect on financial performance.

Portuguese companies convert information and knowledge into their operational activities more easily than Brazilian companies. In addition, Portuguese companies may be experiencing lower costs for the transformation and exploitation of the acquired and assimilated knowledge base (RACAP). Portuguese companies may be more focused on transformation and exploration than Brazilian companies, which are more focused on acquisition and assimilation. The members of Portuguese companies can focus mainly on training in the use and application of knowledge in operational activities (e.g., processes and routines), which can contribute to the efficiency and generation of financial results (Brettel et al., 2011; Patel et al., 2015).

Therefore, the main idea of Zahra and George's (2002) thinking is the complementarity of the concepts of PACAP and RACAP. Therefore, PACAP and RACAP have different roles, but their effect is not isolated, but complementary (Leal-Rodríguez \& Roldán, 2013). The dimensions of absorption capacity exist simultaneously and influence the company's financial performance. Thus, the way to reduce the difference between PACAP and RACAP is to invest in interorganizational relationships (e.g., competitors, suppliers, and customers), in order to develop relational learning through the sharing of information and knowledge, especially when carrying out joint activities (Leal-Rodríguez \& Roldán, 2013). In addition, Pereira and Leitão (2016) identified that Portuguese companies, active in low and mid-tech sectors, tend to cooperate more with their competitors. In this sense, cooperation can be advantageous for companies that know how to take ownership and have better ACAP. Cooperation is the basis for relational exchanges, such as the exchange of information and knowledge (Bengtsson \& Kock, 1999). 


\section{CONCLUSION}

The objective of the study was to assess the effect of absorptive capacity on the financial performance of companies that operate in low-tech sectors, based on a study with Brazilian and Portuguese companies. Thus, it was identified that there is influence of ACAP and its two dimensions on the financial performance of companies, both in the Brazilian and Portuguese context.

The effects of PACAP and RACAP on the financial performance of companies in different contexts indicate differences in results. In Portuguese companies, PACAP has less influence on financial performance than RACAP, while in Brazilian companies, PACAP has more influence on financial performance than RACAP. These results indicate that dimensions contribute differently to the financial performance of companies (Chauvet, 2014), especially in low-tech sectors and in different contexts (e.g., Brazil and Portugal).

In this sense, the study has as a managerial contribution, in that the effect of ACAP on financial performance also occurs in low-tech sectors, such as the real estate sector. However, the results indicate that the absorptive capacity behaves differently in different contexts. These results can be used by companies to identify ways to better appropriate external information and knowledge, in order to improve the company's ACAP and, with that, obtain better results since ACAP allows companies to extract information and external knowledge that serve as input for the development of products and services (Martins, 2016).

As an academic contribution, this study used a scale adapted to measure ACAP in a low-tech sector. Thus, scales validated on ACAP were selected, removing the variables that dealt with innovation and the adapted scale was validated after data collection. Thus, this scale can be used to measure ACAP in other sectors that do not constantly promote product and process innovations.

Thus, the study has some limitations that must be considered. First, the survey was based on the respondents' individual perceptions (i.e., entrepreneurs and/or managers) and, to obtain these perceptions, a single data collection technique (i.e., questionnaire) was used. Second, the convenience sampling technique was used, with two groups of respondents, whose number of participants was reduced (i.e. 29 and 43), which does not allow the results to be generalized. Finally, a study was carried out in different geographic contexts (i.e., Brazil and Portugal), but which have a cultural proximity (Costa, 2006; Silva, 2005) and, in a low technological intensity sector (real estate sector). For these reasons, care must be taken when generalizing these results and conclusions to other different scenarios or contexts (Leal-Rodríguez \& Roldán, 2013).

Therefore, in future studies it is suggested to investigate factors that minimize the differences between the dimensions of ACAP (i.e., PACAP and RACAP), especially those arising from interorganizational relationships (e.g., competitors, suppliers and customers), which promote sharing information and knowledge (Leal-Rodríguez \& Roldán, 2013). In addition, it is opportune to investigate the effect of ACAP on financial performance in low-tech service sectors, based on the dimensions and components of ACAP (Ali et al., 2016; Guo et al., 2017). 


\section{REFERENCES}

Abbate, T., Cesaroni, F., \& Presenza, A. (2020). Knowledge transfer from universities to low- and medium-technology industries: evidence from Italian winemakers. Journal Technology Transfer, 1-28. https://doi.org/10.1007/s10961-020-09800-x

Adejuwon, O. O. (2016). Bridging gaps in innovation systems for small-scale agricultural activities in sub-Saharan Africa: Brokers wanted! Innovation and Development, 6(2), 175-193. https://doi. org/10.1080/2157930X.2016.1195089

Akerlof, G. (1970). The market for "lemons": quality and uncertainly and the market mechanism. Quaterly Journal of Economics, 84(3), 488-500. https://doi.org/10.1016/B978-0-12-2148507.50022-X

Ali, M., Kan, K. A. S., \& Sarstedt, M. (2016). Direct and configurational paths of absorptive capacity and organizational innovation to successful organizational performance. Journal of Business Research, 69(11), 5317-5323. https://doi.org/10.1016/j.jbusres.2016.04.131

Alves, J. N., Balsan, L. A. G., Bazzo, P. S., Lubeck, R. M., \& Grohmann, M. Z. (2010). Redes de cooperação de pequenas e médias empresas: os fatores competitivos aplicados em uma rede de imobiliárias. Gestão \& Regionalidade, 26(78), 18-35. http://dx.doi.org/10.13037/ gr.vol26n78.287

Barney, J. B. (1986). Strategic factor markets: expectations, luck, and business strategy. Management Science, 32(10), 1231-1241. https://doi.org/10.1287/mnsc.32.10.1231

Barney, J. B. (1991). Firm Resources and Sustained Competitive Advantage. Journal of Management, 17(1), 99-120. https://doi.org/10.1177/014920639101700108

Barney, J. B., \& Arikan, A. M. (2001). The resource-based view: origins and implications. In M. A. Hitt, R. E. Freeman, \& J. S. Harrison (Eds.), The Blackwell Handbook of Strategic Management (pp. 124-188). Thousand Oaks: Sage Publications. https://doi.org/10.1177/014920639101700107

Bengtsson, M., \& Kock, S. (1999). Cooperation and competition in relationships between competitors in business networks. Journal of Business \& Industrial Marketing, 14(3), 178-191. https://doi. org/10.1108/08858629910272184

Biedenbach, T., \& Müller, R. (2012). Absorptive, innovative and adaptive capabilities and their impact on project and project portfolio performance. International Journal of Project Management, 30(5), 621-635. https://doi.org/10.1016/j.ijproman.2012.01.016

Brettel, M., Greve, G. I., \& Flatten, T. C. (2011). Giving up linearity: absorptive capacity and performance. Journal of Managerial Issues, 23, 164-189. https://www.jstor.org/stable/23209224

Burcharth, A. L. L. A., Lettl, C., \& Ulhoi, J. P. (2015). Extending organizational antecedents of absorptive capacity: Organizational characteristics that encourage experimentation. Technological Forecasting and Social Change, 90, 269-284. https://doi.org/10.1016/j.techfore.2013.12.024

Camisón, C., \& Forés, B. (2010). Knowledge absorptive capacity: new insights for its conceptualization and measurement. Journal of Business Research, 63(7), 707-715. https://doi.org/10.1016/j. jbusres.2009.04.022

Cassol, A., Cintra, R. F., Ruas, R. L., \& Oldoni, L. E. (2016). Desenvolvimento da capacidade absortiva em empresas incubadas e graduadas de Santa Catarina, Brasil. Desenvolvimento em Questão, 14(37), 168-201. https://doi.org/10.21527/2237-6453.2016.37.168-201 
Centenaro, A., \& Laimer, C. G. (2017). Cooperative relationships and competitiveness in supermarket sector. Revista Brasileira de Gestão de Negócios, 19(63), 65-81. https://doi.org/10.7819/rbgn.v0i0.3070

Chauvet, V. (2014). Absorptive capacity: Scale development and implications for future research. Management International, 19(1), 113-129. https://doi.org/10.7202/1028493ar

Cho, S. W. (2014). The evaluation on the three critical models of absorptive capacity: A case study on logistics company in Korea. Universal Journal of Industrial and Business Management, 2(5), 119-125. https://doi.org/10.13189/ujibm.2014.020502

Cohen, W. M., \& Levinthal, D. A. (1990). Absorptive capacity: a new perspective on learning and innovation. Administrative Science Quarterly, 35(1), 128-152. https://doi.org/10.2307/2393553

Costa, C. G. (2006). Proximidade cultural e dinamismo econômico: por que investem as empresas portuguesas no Brasil. Revista de Administração de Empresas, 46(edição especial), 35-47. https:// doi.org/10.1590/S0034-75902006000500003

Cruz, M. A., \& Corrêa, V. S. (2018). Capacidade absortiva e laços sociais: um modelo teórico integrado. Revista de Administração de Roraima, 8(2), 504-526. https://doi.org/10.18227/22378057 rarr.v8i2.4860

Del Carpio-Gallegos, J. F., \& Miralles Torner, F. (2018). Absorptive capacity and innovation in lowtech companies in emerging economies. Journal of technology management \& innovation, 13(2), 3-11. https://doi.org/10.4067/S0718-27242018000200003

Dess, G. G., \& Robinson JR, R. B. (1984). Measuring organizational performance in the absence of objective measures: The case of the privately-held firm and conglomerate business unit. Strategic Management Journal, 5(1), 265-273. https://doi.org/10.1002/smj.4250050306

Eisenhardt, K. M.; Martin, J. A. (2000). Dynamic capabilities: what are they? Strategic Management Journal, 21(10/11), 1105-1121. https://doi.org/10.1002/1097-0266(200010/11)21:10/11<1105::AIDSMJ133>3.0.CO;2-E

Fernández, F. G., Limón, M. S., \& Morales, J. Á. S. (2012). Absorptive capacities of local enterprises $\mathrm{f}$ rom the electric-electronics sector in the state of Tamaulipas, Mexico. Journal of Technology Management \& Innovation, 7(1), 128-143. http://dx.doi.org/10.4067/S0718-27242012000100009

Ferreira, G. C., \& Ferreira, J. J. M. (2017). Absorptive capacity: an analysis in the context of Brazilian family firms. Mackenzie Management Review, 18(1), 174-204. https://doi.org/10.1590/167869712017/administracao.v18n1p174-204

Field, A. (2009). Descobrindo a estatística usando o SPSS [recurso eletrônico] (2nd ed.). Porto Alegre: Artmed.

Flatten, T. C., Engelen, A., Zahra, S. A., \& Brettel, M. (2011). A measure of absorptive capacity: scale development and validation. European Management Journal, 29(2), 98-116. https://doi. org/10.1016/j.emj.2010.11.002

Flatten, T. C., Greve, G. I., \& Brettel, M. (2011). Absorptive capacity and firm performance: the mediating influence of strategic alliances. European Management Review, 8, 137-152. https:// doi.org/10.1111/j.1740-4762.2011.01015.x

Flor, M. L., Cooper, S. Y., \& Oltra, M. J. (2018). External knowledge search, absorptive capacity and radical innovation in high-technology firms. European Management Journal, 36(2), 183-194. https://doi.org/10.1016/j.emj.2017.08.003 
BBR

18

Galindo-Rueda, F., \& Verger, F. (2016). OECD taxonomy of economic activities based on R\&D intensity. OECD Science, Technology and Industry Working Papers No. 2016/04. Paris: OECD Publishing. https://doi.org/10.1787/5jlv73sqqp8r-en

Gann, D. (2010). Putting academic ideas into practice: technological progress and the absorptive capacity of construction organizations. Construction Management and Economics, 19(3), 321-330. https://doi.org/10.1080/01446190010020480

Garzón-Castrillón, M. A. (2016). Capacidad dinámica de absorción. Estudio de caso. ORINOQUIA, 20(1), 97-118. http://www.scielo.org.co/pdf/rori/v20n1/v20n1a11.pdf

Geldes, C., Felzensztein, C., \& Palacios-Fenech, J. (2017). Technological and non-technological innovations, performance and propensity to innovate across industries: The case of an emerging economy. Industrial Marketing Management, 61, 55-66. https://doi.org/10.1016/j. indmarman.2016.10.010

Giuliani, E., \& Bell, M. (2005). The micro-determinants of meso-level learning and innovation: Evidence from a Chilean wine cluster. Research Policy, 34(1), 47-68. https://doi.org/10.1016/j. respol.2004.10.008

Guo, Y., Zheng, G., \& Liu, F. (2017). Non-R\&D-based innovation activities and performance in Chinese SMEs: the role of absorptive capacity. Asian Journal of Technology Innovation, 25(1),110128. https://doi.org/10.1080/19761597.2017.1302548

Gwebu, K. L., Sohl, J., \& Wang, J. (2018). Differential performance of science park firms: an integrative model. Small Business Economics, 52, 193-211. https://doi.org/10.1007/s11187-018-0025-5

Hair, J. F., Jr., Babin, B., Money, A. H., \& Samouel, P. (2009). Fundamentos de métodos de pesquisa em administração. Porto Alegre: Bookman.

Hernández-Perlines, F., \& Xu, W. (2018). A mediation model of absorptive and innovative capacities: the case of Spanish family businesses. In Simpósio Internacional de Computação Distribuida e Inteligência Artificial (pp. 83-90). https://doi.org/10.1007/978-3-319-99698-1

Hervas-Oliver, J. L., Albors-Garrigos, J., de-Miguel, B., \& Hidalgo, A. (2012). The role of a firm's absorptive capacity and the technology transfer process in clusters: How effective are technology centres in low-tech clusters?. Entrepreneurship \& Regional Development, 24(78), 523-559. https:// doi.org/10.1080/08985626.2012.710256

Hodge, D. R., \& Gillespie, D. (2003). Phrase completions: An alternative to Likert scales. Social Work Research, 27(1), 45-55. https://doi.org/10.1093/swr/27.1.45

Instituto Nacional de Estatística [INE]. (2019). Empresas: estatísticas territoriais - Aveiro 2018. Recuperado em 21 dezembro 2019, de: https://portal-rpe01.ine.pt/xportal/xmain?xpid=INE\&xpgid=ine_unid_ territorial \&menuBOUI=13707095\&contexto $=u t \& s e l T a b=t a b 3$.

Jansen, J. J. P., Van Den Bosch, F. a J., \& Volberda, H. W. (2005). Managing potential and realised absorptive capacity: How do organisational antecedents matter? Academy of Management Journal, 48(6), 999-1015. https://doi.org/10.5465/AMJ.2005.19573106

Jiménez-Barrionuevo, M. M., García-Morales, V. J., \& Molina, L. M. (2011). Validation of an instrument to measure absorptive capacity. Technovation, 31(5-6), 190-202. https://doi.org/10.1016/j. technovation.2010.12.002

Kale, E., Aknar, A., \& Başar, Ö. (2019). Absorptive capacity and firm performance: The mediating role of strategic agility. International Journal of Hospitality Management, 78, 276-283. https://doi. org/10.1016/j.ijhm.2018.09.010 
Kamal, E. M., \& Flanagan, R. (2012). Understanding absorptive capacity in Malaysian small and medium sized (SME) construction companies. Journal of Engineering, Design and Technology., 10(2), 180-198. https://doi.org/10.1108/17260531211241176

Kim, C., \& Lee, J. (2018). The effect of network structure on performance in South Korea SMEs : The moderating effects of absorptive capacity. Sustainability, 10(9), 2-14. https://doi.org/10.3390/ su10093174

Kline, R. B. (2011). Convergence of Structural Equation Modeling and Multilevel Modeling. In M. Williams \& W. P. Vogt (Eds.), The SAGE Handbook of Innovation in Social Research Methods (pp. 562-589). London: Sage Publications.

Kostopoulos, K., Papalexandris A., Papachroni M., \& Ioannou, G. (2011). Absorptive capacity, innovation, and financial performance. Journal of Business Research, 64(12), 1335-1343. https:// doi.org/10.1016/j.jbusres.2010.12.005

Lane, P. J., Koka, B. R., \& Pathak, S. (2006). The reification of absorptive capacity: a critical review and rejuvenation of the construct. Academy of Management Review, 31(4), 833-863. https://doi. org/10.5465/amr.2006.22527456

Leal-Rodríguez, A. L., \& Roldán, J. L. (2013). The moderating role of relational learning on the PACAP - RACAP link . A study in the Spanish automotive components manufacturing sector. Revista Europea de Dirección y Economía de La Empresa, 22(4), 218-224. https://doi.org/10.1016/j. redee.2013.07.002

Lee, C. Y., \& Wu, F. C. (2010). Factors affecting knowledge transfer and absorptive capacity in multinational corporations. The Journal of International Management Studies, 5(2), 118-126. https://doi.org/10.1111/ijtd.12077

Liao, Y., Yi, X., \& Jiang, X. (2019). Unlocking the full potential of absorptive capacity: the systematic effects of high commitment work systems. The International Journal of Human Resource Management, 1-28. https://doi.org/10.1080/09585192.2018.1522655

Liu, X., Zhao, H., \& Zhao, X. (2018). Absorptive capacity and business performance: The mediating effects of innovation and mass customization. Industrial Management Data Systems, 118(9), 17871803. https://doi.org/10.1108/IMDS-09-2017-0416

Malhotra, N. K. (2012). Pesquisa de marketing: uma orientação aplicada. Porto Alegre: Bookman.

Martins, J. T. (2016). Relational capabilities to leverage new knowledge managing directors' perceptions in UK and Portugal old industrial regions. The Learning Organization, 23(6), 398-414. https:// doi.org/10.1108/TLO-03-2016-0022

Maurer, I., Bartsch, V., \& Ebers, M. (2011). The value of intra-organizational social capital: How it fosters knowledge transfer, innovation performance, and growth. Organization Studies, 32(2), 157-185. https://doi.org/10.1177/0170840610394301

Mazzola, E., Perrone, G., \& Kamuriwo, D. S. (2016). Network positions and the probability of being acquired: An empirical analysis in the biopharmaceutical industry. British Journal of Management, 27(3), 516-533. https://doi.org/10.1111/1467-8551.12174

Melo, T. M., Fucidji, J. R., \& Possas, M. L. (2015). Política industrial como política de inovação: notas sobre hiato tecnológico, políticas, recursos e atividades inovativas no Brasil. Revista Brasileira de Inovação, 14(n. Esp.), 11-36. https://doi.org/10.20396/rbi.v14i0.8649098

Ministério da Economia. (2019). Secretária de Trabalho: Relação Anual de Informações Sociais (RAIS) 2018. Recuperado em 21 dezembro 2019, de: http://pdet.mte.gov.br/rais. 
BBR

18

556

Muscio, A. (2007). The impact of absorptive capacity on SMEs' collaboration. Economics of Innovation and New Technology, 16(8), 653-668. https://doi.org/10.1080/10438590600983994

Najafi-Tavani, Z., Robson, M. J., Zaefarian, G., Andersson, U., \& Yu, C. (2018). Building subsidiary local responsiveness: (When) does the directionality of intrafirm knowledge transfers matter? Journal of World Business, 53(4), 475-492. https://doi.org/10.1016/j.jwb.2018.01.004

Patel, P. C., Kohtamäki, M., Parida, V., \& Wincent, J. (2015). Entrepreneurial orientation-asexperimentation and firm performance: The enabling role of absorptive capacity. Strategic Management Journal, 36(11), 1739-1749. https://doi.org/10.1002/smj.2310

Patterson, W., \& Ambrosini, V. (2015). Configuring absorptive capacity as a key process for research intensive firms. Technovation, 36-37, 77-89. https://doi.org/10.1016/j.technovation.2014.10.003

Penrose, E. (2006). A teoria do crescimento da firma. Campinas: UNICAMP.

Pereira, D., \& Leitão, J. (2016). Absorptive capacity, coopetition and generation of product innovation: contrasting Italian and Portuguese manufacturing firms. International Journal Technology Management, 71(1/2), 10-37. https://doi.org/10.1504/IJTM.2016.077979

Pollanen, R., Abdel-Maksoud, A., Elbanna, S., \& Mahama, H. (2017). Relationships between strategic performance measures, strategic decision-making, and organizational performance: empirical evidence from Canadian public organizations. Public Management Review, 19(5), 725-746. https:// doi.org/10.1080/14719037.2016.1203013

Roberts, N., Galluch, P. S., Dinger, M., \& Grover, V. (2012). Absorptive capacity and information systems research: rewiew, synthesis, and directions for future research. MIS Quarterly, 36(2), 625648. https://doi.org/10.2307/41703470

Sánchez, E. O. P., \& Toro-Jaramillo, I.-D. (2018). Study of the realized absorptive capacity in the organizations of Colombia and Brazil. Journal of Industrial Engineering and Management, 11(4), 617-631. http://dx.doi.org/10.3926/jiem.2634

Schilke, O. (2013). 'On the contingent value of dynamic capabilities for competitive advantage: the nonlinear moderating effect of environmental dynamism', Strategic Management Journal, 35(2), 179-203. https://doi.org/10.1002/smj.2099

Shoham, A., Asseraf, Y., Lev, S., \& Fiegenbaum, A. (2017). Marketing and technological absorptive capacities: Environmental antecedents and performance outcomes in high-tech firms. Journal of Business-to-Business Marketing, 24(3), 165-182. https://doi.org/10.1080/1051712X.2017.1345258

Silva, J. R. (2005). A internacionalização das empresas portuguesas: a experiência brasileira. Revista de Administração de Empresas, 45(edição especial), 102-115. http://dx.doi.org/10.1590/S003475902005000500008

Spithoven, A., Clarysse, B., \& Knockaert, M. (2011). Building absorptive capacity to organise inbound open innovation in traditional industries. Technovation, 31(1), 10-21. https://doi.org/10.1016/j. technovation.2010.10.003

Sroka, W., Cygler, J., \& Gajdzik, B. (2014). The transfer of knowledge in intra-organizational networks: A case study analysis. Organizacija, 47(1), 24-34. https://doi.org/10.2478/orga-2014-0003

Teece, D. J., Pisano, G., \& Shuen, A. (1997). Dynamic capabilities and strategic management. Strategic Management Journal, 18(7), 509-533. https://doi.org/10.1002/(SICI) 10970266(199708) 18:7<509::AID-SMJ882>3.0.CO;2-Z

Todorova, G., \& Durisin, B. (2007). Absorptive capacity: Valuing a reconceptualization. Academy of Management Review, 32(3), 774-786. https://doi.org/10.5465/ar.2007.25275513 
Tsai, W. (2001). Knowledge transfer in intraorganizational networks: Effects of network position and absorptive capacity on business unit innovation and performance. Academy of Management Journal, 44(5), 996-1004. https://doi.org/10.1002/sres.1074

Tzokas, N., Kim, Y. A., Akbar, H., \& Al-Dajani, H. (2015). Absorptive capacity and performance: The role of customer relationship and technological capabilities in high-tech SMEs. Industrial Marketing Management, 47, 134-142. https://doi.org/10.1016/j.indmarman.2015.02.033

Volberda, H.W., Foss, N.J., \& Lyles, M.A. (2010). Absorbing the concept of absorptive capacity: how to realize its potential in the organization field. Organization Science, 21(4), 934-954. https:// doi.org/10.1287/orsc. 1090.0503

Vega-Jurado, J., Gutiérrez-Gracia, A., \& Fernández-de-Lucio, I. (2008). Analyzing the determinants of firm's absorptive capacity: beyond P\&D. RङD Management, 38(4), 392-405. https://doi. org/10.1111/j.1467-9310.2008.00525.x

Wang, C. L., \& Ahmed, P. K. (2007). Dynamic capabilities: A review and research agenda. International Journal of Management Reviews, 9(1), 31-51. https://doi.org/10.1111/j.1468-2370.2007.00201.x

Wang, C. L., \& Rafiq, M. (2014). Ambidextrous organizational culture, contextual ambidexterity and new product innovation: a comparative study of UK and Chinese high-tech firms. British Journal of Management, 25(1), 58-76. https://doi.org/10.1111/j.1467-8551.2012.00832.x

Wang, C. L., Senaratne, C., \& Rafiq, M. (2015). Success traps, dynamic capabilities and firm performance. British Journal of Management, 26(1), 26-44. https://doi.org/10.1111/14678551.12066

Wegner, D., Agnes, J. I., Callado, A. L. C., \& Callado, A. A. C. (2016). Cooperar vale a pena? Uma Análise comparativa do desempenho de empresas em rede, participantes de franquias e empresas individuais. Revista de Administração Unimep, 14(1), 80-113. https://doi.org/10.15600/16795350/rau.v14n1p80-113

Wegner, D., Koetz, C. I., \& Wilk, E. de O. (2013). Social capital in Brazilian small-firm networks: the influence on business performance. International Journal of Entrepreneurship and Small Business, 20(4), 446-461. https://doi.org/10.1504/IJESB.2013.057201

Wernerfelt, B. (1984). A Resource-Based View of the Firm. Strategic Management Journal, 5(2), 171-180. https://doi.org/10.1002/smj.4250050207

Xie, X., Zou, H., \& Qi, G. (2018). Knowledge absorptive capacity and innovation performance in high-tech companies: A multi-mediating analysis. Journal of Business Research, 88(9), 289-297. https://doi.org/10.1016/j.jbusres.2018.01.019

Yadav, R., \& Pathak, G. S. (2016). Intention to purchase organic food among young consumers: Evidences from a developing nation. Appetite, 96(9), 122-128. https://doi.org/10.1016/j. appet.2015.09.017

Yu, S. (2013). Social capital, absorptive capability, and firm innovation. Technological Forecasting and Social Change, 80(7), 1261-1270. https://doi.org/10.1016/j.techfore.2012.12.005

Zahra, S. A., \& George, G. (2002). Absorptive capacity: a review, reconceptualization, and extension. The Academy of Management Review, 27(2), 185-203. https://doi.org/10.5465/amr.2002.6587995

Zou, T., Ertug, G., \& George, G. (2018). The capacity to innovate: A meta-analysis of absorptive capacity. Innovation, 20(2), 87-121. https://doi.org/10.1080/14479338.2018.1428105 
BBR

18

558

\section{AUTHOR'S CONTRIBUTION}

Research planning (author 1, 2, 3, 4); literature review (author 1, 2); definition of methodological procedures (author 1, 2); data collection (author 1, 2, 3, 4); analysis and interpretation of data (author 1, 2, 3, 4); manuscript writing (author 1,2); and critical revision of the manuscript (author 1, 2, 3, 4).

The authors declare that there are no conflicts of interest with the investigation and publication of the article. 
Considering the statements below, indicate your level of agreement, where 0 means that you totally disagree with the statement and 10 that you completely agree with the statement.

\begin{tabular}{|c|c|c|c|}
\hline \multicolumn{4}{|c|}{ ACAP (acquisition) } \\
\hline Acronym & Statement & Avg & S.D. \\
\hline CA_Acqui_1 & $\begin{array}{l}\text { The search for relevant information about our sector is a daily } \\
\text { activity in our company. }\end{array}$ & 8.43 & 1.63 \\
\hline CA_Acqui_1 & $\begin{array}{l}\text { The company has frequent contact with other companies in the } \\
\text { sector to acquire new knowledge. }\end{array}$ & 6.75 & 2.75 \\
\hline CA_Acqui_1 & $\begin{array}{l}\text { The company organizes special meetings with customers, suppliers } \\
\text { or third parties to acquire new knowledge. }\end{array}$ & 6.28 & 2.89 \\
\hline CA_Acqui_1 & $\begin{array}{l}\text { We have frequent interactions with other companies in the } \\
\text { sector in order to acquire new knowledge related to product } \\
\text { development. }\end{array}$ & 6.26 & 2.92 \\
\hline CA_Acqui_1 & $\begin{array}{l}\text { We collect information informally (for example, lunches or social } \\
\text { gatherings with customers and suppliers, business partners and } \\
\text { other interested parties). }\end{array}$ & 6.85 & 2.62 \\
\hline \multicolumn{4}{|c|}{ ACAP (assimilation) } \\
\hline Acronym & Statement & Avg & S.D. \\
\hline CA_Assim_1 & $\begin{array}{l}\text { The company is able to use the knowledge, experience and } \\
\text { skills of employees in the assimilation and interpretation of new } \\
\text { knowledge. }\end{array}$ & 8.11 & 1.94 \\
\hline CA_Assim_2 & $\begin{array}{l}\text { The company is able to quickly identify new opportunities to } \\
\text { meet customer needs. }\end{array}$ & 8.39 & 1.53 \\
\hline CA_Assim_3 & $\begin{array}{l}\text { The company quickly analyzes and interprets the ever-changing } \\
\text { market demands. }\end{array}$ & 8.29 & 1.37 \\
\hline CA_Assim_4 & $\begin{array}{l}\text { The company has a rapid flow of information, for example, if a } \\
\text { business unit obtains important information, it communicates } \\
\text { that information immediately to all other business units or } \\
\text { departments. }\end{array}$ & 7.86 & 2.23 \\
\hline CA_Assim_5 & $\begin{array}{l}\text { Our administration requires periodic meetings between } \\
\text { departments to exchange new developments, problems and } \\
\text { achievements. }\end{array}$ & 7.38 & 2.55 \\
\hline
\end{tabular}

\section{ACAP (transformation)}

\begin{tabular}{c|l|c|c}
\hline Acronym & Statement & Avg & S.D. \\
\hline CA_Transf_1 & $\begin{array}{l}\text { Employees have the ability to structure and use the knowledge } \\
\text { collected. }\end{array}$ & 8.22 & 1.27 \\
\hline CA_Transf_2 & $\begin{array}{l}\text { Employees are available to absorb new knowledge, as well as to } \\
\text { prepare it for other purposes and make it available to others. }\end{array}$ & 8.14 & 1.34 \\
\hline CA_Transf_3 & Employees associate existing knowledge with new ideas. & 8.13 & 1.46 \\
\hline CA_Transf_4 & Employees can apply new knowledge to their practical work. & 8.58 & 1.17 \\
\hline CA_Transf_5 & $\begin{array}{l}\text { The company regularly considers the consequences of changes in } \\
\text { market demands in terms of new products and services. }\end{array}$ & 8.32 & 1.25 \\
\hline
\end{tabular}

ACAP (exploration)

\begin{tabular}{c|l|c|c}
\hline Acronym & Statement & Avg & S.D. \\
\hline CA_Expl_1 & $\begin{array}{l}\text { The company regularly reconsiders technologies and adapts them } \\
\text { according to the new knowledge. }\end{array}$ & 8.21 & 1.84 \\
\hline
\end{tabular}




\section{ACAP (acquisition)}

\begin{tabular}{c|l|c|c}
\hline CA_Expl_2 & $\begin{array}{l}\text { The company has the ability to work more effectively by adopting } \\
\text { new technologies. }\end{array}$ & 8.47 & 1.75 \\
\hline CA_Expl_3 & The company often considers how to best exploit knowledge. & 8.15 & 1.43 \\
\hline CA_Expl_4 & $\begin{array}{l}\text { The company is able to use and explore new knowledge in the } \\
\text { workplace to respond quickly to changes in the environment. }\end{array}$ & 8.24 & 1.50 \\
\hline CA_Expl_5 & $\begin{array}{l}\text { The company has the capacity to place technological knowledge } \\
\text { in product and process patents. }\end{array}$ & 6.46 & 2.86 \\
\hline & \multicolumn{1}{|c}{ Performance } & Avg & S.D. \\
\hline Acronym & Statement & 7.44 & 2.12 \\
\hline Perform_1 & $\begin{array}{l}\text { There has been an increase in the company's revenue in recent } \\
\text { years. }\end{array}$ & 7.15 & 2.13 \\
\hline Perform_2 & There has been growth in the company's sales in recent years. & 3.00 \\
\hline Perform_3 & There has been a reduction in the company's costs in recent years. & 5.18 & 1.97 \\
\hline Perform_4 & $\begin{array}{l}\text { There has been an increase in the company's profitability in recent } \\
\text { years. }\end{array}$ & 7.13 & 2.02 \\
\hline Perform_5 & $\begin{array}{l}\text { There has been an increase in the company's productivity in recent } \\
\text { years. }\end{array}$ & 7.32 & 2.25 \\
\hline Perform_6 & There has been an increase in the company's profit in recent years. & 7.10 & \\
\hline
\end{tabular}

Note: Avg = average, S.D. = Standard Deviation

Source: Prepared by the authors based on the literature. 